\title{
Efektivitas Hasil Belajar IPA Melalui Model Discovery Learning Berbantuan Media Visual Siswa Kelas IV SD
}

\author{
Kadek Savitri \\ Program Studi Pendidikan Guru Sekolah Dasar, Universitas Pendidikan Ganesha \\ savitri.kadek91@gmail.com
}

I Made Citra Wibawa

Program Studi Pendidikan Guru Sekolah Dasar, Universitas Pendidikan Ganesha imadecitra.wibawa@undiksha.ac.id

\begin{tabular}{l} 
A R T I C L E I N F O \\
\hline Article history: \\
1 Januari 2020 Received in \\
revised form \\
30 Mei 2020 \\
Accepted 30 Juni 2020 \\
Available online \\
15 Juli 2020 \\
\hline Kata Kunci: \\
Hasil Belajar, Discovery \\
Learning \\
Keywords: \\
Learning Outcomes, \\
Discovery Learning
\end{tabular}

\begin{abstract}
ABSTRAK
Rendahnya hasil belajar siswa pada mata pelajaran IPA serta kecenderungan siswa menghafal materi mengakibatkan siswa jarang menemukan sendiri konsep atau prinsip materi yang dibelajarkan. Penelitian ini bertujuan untuk mengetahui pengaruh yang signifikan model pembelajaran discovery learning berbantuan media visual terhadap hasil belajar IPA siswa kelas IV SD. Populasi penelitian ini berjumlah 179 orang siswa di kelas IV SD. Jenis penelitian ini adalah eksperimen semu dengan desain non-equivalent post-test only control group design. Metode pengumpulan data yang digunakan adalah
\end{abstract} metode tes berupa pilihan ganda. Metode analisis data yang digunakan yaitu uji-t. Hasil penelitian menunjukan bahwa $t_{\text {hitung }}=3,95>t_{\text {tabel }}=2,000$ dengan kriteria pengujian $\mathrm{t}_{\text {hitung }}(3,95)>\mathrm{t}_{\text {tabel }}(2,000)$, sehingga $\mathrm{H}_{0}$ ditolak dan $\mathrm{H}_{1}$ diterima. Dengan demikian, model discovery learning berbantuan media visual berpengaruh terhadap hasil belajar IPA siswa kelas IV SD. Dengan hal ini membuktikan bahwa model discovery leaning berbantuan media visual berpengaruh posistif terhadap peningkatan hasil belajar IPA siswa kelas IV SD.

\section{AB S T R A K}

The low student learning outcomes in natural science lessons and the tendency of students to memorize the material so that students rarely find their own concept or principles of material being taught. This study aimed to determing the significant effect of discovery learning models assisted by visual media on the learning outcomes of science students in grade IV elementary school. The study population numbered 179 students in grade IV elementary school. This type of research is a quasiexperimental design with a non-equivalent post-test only control group design. The data collection method used is a multiple choice test method. Data analysis method used is t-test. The results of the study showed tcount $=3.95>\mathrm{t}$ table $=2,000$ with the test criteria $t_{\text {count }}(3.95)>t_{\text {table }}(2,000)$, so H0 was rejected and H1 was accepted. The discovery learning model assisted by visual media has an effect on the learning outcomes of grade IV students in Natural Sciences. Meanwhile it proves that the discovery leaning model assisted by visual media has a positive effect on the improvement of science learning outcomes of fourth grade elementary school students. 


\section{PENDAHULUAN}

Pendidikan merupakan aktivitas yang berlangsung sepanjang hidup manusia. Berkaitan dengan hal terebut pendidikan memberikan perubahan yang sangat besar bagi kehidupan manusia. Utami, dkk., (2018) mengemukakan pendidikan memberikan peranan penting untuk membentuk individu yang cerdas, berakhlak mulia dan takwa kepada Tuhan. Selain itu, pendidikan dapat meningkatkan kualitas diri individu untuk masa depan. Mengacu pada hal tersebut, pendidikan yang sesuai dan berkualitas adalah suatu kegiatan belajar mengajar yang didukung oleh proeses pembelajaran yang efektif, siswa cepat memahami apa yang diajarkan, pengadaan sarana dan prasarana yang lengkap di masingmasing sekolah dan pembaharuan kurikulum yang dikemukakan oleh (Putrayasa, dkk., 2014). Kurikulum yang diterapkan saat ini di Indonesia adalah kurikulum 2013.

Kurikulum 2013 pada pengembangan materi-materi yang dulu dirancang 1 mata pelajaran dikembangkan menjadi materi-materi terintegrasi dan terpadu dalam suatu tema yang disebut tematik terpadu. Armini, dkk., (2017) menyatakan IPA merupakan pelajaran pokok di SD dimaksudkan agar siswa mempunyai pengetahuan, gagasan, dan konsep yang terorganisasi tentang alam sekitar. Suatu konsep pembelajaran alam yang merupakan pengetahuan dari hasil kegiatan manusia yang diperoleh dari hasil eksperimen atau observasi dengan menggunakan metode ilmiah. Menurut Trianto (dalam Rediarta, 2014) IPA adalah pengetahuan yang sistematis dan dirumuskan yang berhubungan dengan gejalagejala kebendaan dan didasarkan pengamatan. Dalam hal ini siswa bisa mempelajari gejalagejala alam sekitar melalui pengamatan langsung yang dilakukan untuk mencapai tujuan pembelajaran IPA.

Pada hakikatnya pembelajaran IPA didefinisikan sebagai ilmu tentang alam, dapat diklasifikasikan menjadi tiga bagian, yaitu: ilmu pengetahuan alam sebagai produk, proses, dan sikap. Menurut Riastini (2016) ketiga komponen ini diharapkan dapat memahami konsep-konsep IPA yang terkait dalam kehidupan sehar-hari. Pada tingkat SD, pembelajaran IPA hendaknya membuka kesempatan kepada siswa untuk memupuk rasa ingin tahu secara alamiah yang nantinya akan membantu mereka mengembangkan kemampuan bertanya dan mencari jawaban berdasarkan bukti serta mengembangkan cara berpikir ilmiah. Menurut Dewi, dkk. (2016) pembelajaran IPA di SD dapat dilakukan dengan penyelidikan sederhana terhadap kumpulan konsep IPA, melalui penyelidikan sederhana siswa akan mendapatkan pengalaman langsung dalam belajar. Dalam hal ini siswa dapat terlibat langsung dalam proses pembelajaran. Tujuan IPA secara umum adalah membantu agar siswa memahami konsep IPA dan keterkaitannya dengan kehidupan seharihari serta dalam proses pembelajaran guru seharusnya mampu membuat pembelajaran IPA di kelas menjadi menyenangkan dengan melibatkan siswa secara aktif (Noviyanti, dkk., 2017). Melalui keterlibatan siswa di dalam proses pembelajaran diharapkan nantinya akan mencapai tujuan dan hasil belajar yang optimal.

Namun, kondisi yang dipaparkan di atas belum sesuai dengan kenyataan di lapangan. Hal ini dibuktikan dari data PISA (Programe for Internasional Student Assessment) kemampuan literasi sains siswa di Indonesia masih di bawah rata-rata jika dibandingkan dengan rerata skor internasional. Sebagaimana dikutip dari The Organization for Economic Co-operation and Development (OECD) pada tahun 2018 menunjukkan skor rata-rata sains siswa di Indonesia yakni 389, sedangkan skor rata-rata OECD yakni 489 (Indriani, 2019). Hal tersebut menunjukkan bahwa posisi nilai sains siswa di Indonesia masih dibawah skor rata-rata dari negara lain di dunia pada umumnya. Siswa Indonesia kurang mampu menggunakan konsep-konsep yang dipelajari di bangku sekolah untuk menyelesaikan masalah nyata dalam kehidupannya (Mahendra, dkk., 2019). Hal ini diperkuat dari hasil wawancara, observasi, dan pencatatan dokumen di Gugus XIII Kecamatan Buleleng Tahun Pelajaran 2019/2020.

Berdasarkan hasil wawancara, observasi, dan pencatatan dokumen yang dilaksanakan pada tanggal 22-24 Oktober 2019 dengan guru kelas IV di Gugus XIII Kecamatan Buleleng. Ditemukan bahwa dalam pelaksanaan pembelajaran IPA masih 
belum sesuai dengan yang diharapkan. Hal ini diperkuat dari hasil wawancara dengan guru kelas IV di gugus XIII Kecamatan Buleleng diperoleh informasi sebagai berikut. 1) Pemanfaatan media pembelajaran dalam proses pembelajaran masih kurang. Media pembelajaran IPA yang ada di sekolah jarang digunakan, sehingga banyak media yang rusak dengan sendiriya.

Selanjutnya dari hasil observasi didapatkan hasil sebagai berikut. 1) Siswa jarang diberikan kesempatan untuk menemukan sendiri konsep atau prinsip dari materi yang dibelajarkan. Hal ini terlihat dari siswa hanya duduk diam mendengarkan penjelasan materi yang disampaikan. 2) Dalam proses pembelajaran lebih menekankan penguasaan materi dengan cara menghafal. Hal ini terlihat dalam proses pembelajaran tidak melakukan penyelidikan sederhana dalam penguasaan materi, sehingga keterlibatan siswa dalam proses pembelajaran masih kurang. 3) Cara penyampaian materi pun kurang menarik perhatian siswa karena tidak diimbangi dengan model pembelajaran yang inovatif. Hal ini menyebabkan pembelajaran kurang terpusat pada siswa sehingga interaksi antar siswa masih kurang.

Selain hasil wawancara dan observasi, didukung dengan hasil pencatatan dokumen terkait nilai pengetahuan IPA. Ditemukan hasil belajar IPA siswa kelas IV masih rendah atau dibawah KKM. Hal tersebut diperkuat dari hasil Ulangan Tengah Semester (UTS) IPA semester ganjil tahun pelajaran 2019/2020 sebagai berikut.

Tabel 1. Rata-rata UTS IPA Siswa Kelas IV Semester Ganjil Tahun Pelajaran 2019/2020

\begin{tabular}{ccccccc}
\hline & & & & & \multicolumn{2}{c}{ Pencapaian KKM } \\
\cline { 6 - 7 } No & Nama Sekolah & Kelas & KKM & $\begin{array}{c}\text { Jumlah } \\
\text { Siswa }\end{array}$ & $\begin{array}{c}\text { Mencapai } \\
\text { KKM }\end{array}$ & $\begin{array}{c}\text { Belum } \\
\text { Mencapai } \\
\text { KKM }\end{array}$ \\
\hline \multirow{2}{*}{1} & SDN 1 Baktiseraga & IV A & 70 & 28 & 12 & 16 \\
2 & SDN 1 Banjar Tegal & IV B & 70 & 34 & 13 & 21 \\
3 & SDN 2 Banjar Tegal & IV & 70 & 28 & 11 & 17 \\
4 & SDN 3 Banjar Tegal & IV & 77 & 25 & 11 & 14 \\
5 & SD Mutiara Singaraja & IV A & 75 & 8 & 4 & 4 \\
& Jumlah & IV B & 75 & 29 & 10 & 19 \\
& & & $\mathbf{1 7 9}$ & $\mathbf{7 3}$ & $\mathbf{1 0 6}$ \\
\hline
\end{tabular}

Mengacu pada Tabel 1 tampak bahwa dari 179 orang siswa kelas IV di Gugus XIII Kecamatan Buleleng jumlah siswa yang mencapai KKM berjumlah 73 orang dan siswa yang belum mencapai KKM sebanyak 106 orang. Hasil tersebut menunjukkan bahwa hasil belajar IPA siswa kelas IV di Gugus XIII Kecamatan Buleleng Tahun Pelajaran 2019/2020 pada aspek pengetahuan masih rendah.

Berdasarkan masalah di atas, apabila hal tersebut dibiarkan akan mengakibatkan hasil belajar IPA siswa rendah. Hal ini terjadi karena siswa kurang bersemangat, cepat bosan, dan mudah mengantuk dalam mengikuti pembelajaran.

Berdasarkan permasalahan yang telah dipaparkan, perlu dicarikan solusi baik menyangkut proses pembelajaran maupun media pembelajaran sehingga pembelajaran yang dilaksanakan dapat memberikan hasil belajar yang baik. Solusi untuk memperbaiki proses pembelajaran dari permasalahan tersebut adalah menerapkan model pembelajaran yang dapat mendorong siswa lebih aktif, kreatif dan menemukan sendiri konsep materi sehingga pembelajaran akan lebih bermakna. Salah satu model pembelajaran yang diduga dapat menjawab permasalahan yang dihadapi adalah model discovery learning. Supradnyana (2016) menyatakan melalui konsep belajar discovery learning pada dasarnya menjelaskan mengenai proses pembentukan belajar dengan jalan menggali dan mencari 
sendiri pengetahuan, pemahaman, pengertian dan konsep-konsep secara mandiri. Menurut Kurniasih \& Sani (2014) model pembelajaran discovery learning merupakan model pembelajaran yang dalam penyampaian materi tidak disampaikan dalam bentuk final, tetapi siswa dituntut untuk mengorganisasi sendiri cara belajarnya dalam menemukan konsep dan saat proses pembelajaran guru akan memberikan semacam masalah yang sudah dibuat sebelumnya. Menurut Purwanti, dkk., (2018) pembelajaran discovery learning mempunyai langkah-langkah sebagi berikut: 1) stimulation (siswa dihadapkan dengan persoalan), 2) problem statement (siswa mengidentifikasi masalah kemudian merumuskan hipotesis, 3) data collection (siswa mengumpulkan data dan informasi yang dibutuhkan dari berbagai sumber), 4) data processing (mengolah data informasi), 5) verification (berdasarkan pengolahan data yang diperoleh kemudian dicek apakah terbukti atau tidak kebenarannya, 6) generalization (menarik kesimpulan). Penerapan model pembelajaran discovery learning di SD terutama pada pembelajaran IPA menjadi sangat tepat dikarenakan model discovery learning memeiliki beberapa kelebihan. Astuti, dkk., (2015) menyatakan model discovery learning memeiliki beberapa kelebihan yaitu: 1) membantu siswa untuk memperbaiki dan meningkatkan keterampilan proses kognitif, 2) menimbulkan rasa senang pada siswa, karena tumbuhnya rasa menyelidiki dan berhasil, 3) menyebabkan siswa mengarah kegiatan belajarnya sendiri dengan melibatkan akalnya dan motivasi sendiri, 4) membantu siswa memperkuat konsepnya sendiri karena memperoleh kepercayaan bekerja sama dengan yang lain, 5) membantu siswa menghilangkan keraguaannskeptisme karena mengarah pada kebenaran yang pasti. Sedangkan Putrayasa, dkk., (2014) menyatakan kelebihan model pembelajaran discovery learning yaitu, 1) menambah pengalaman siswa dalam belajar, 2) memberikan kesempatan kepada siswa untuk lebih dekat lagi dengan sumber pengetahuan selain buku, 3) menggali kreatifitas siswa, 4) mampu meningkatkan rasa percaya diri pada siswa, dan 5) meningkatkan kerja sama antar siswa.

Model discovery learning dipadukan dengan media visual akan sangat membantu siswa dalam proses pembelajaran. Pada pembelajaran IPA konsep materi yang disampaikan cenderung abstrak sehingga siswa sulit untuk memahami konsep materi yang disampaikan. Perlu adanya media visual agar siswa dapat belajar lebih konkret. Susilana \& Riyana (2016) menyatakan media visual yaitu berupa sarana dan prasarana yang dapat memberikan pengalaman visual kepada siswa, antara lain untuk memperjelas konsep yang abstrak dan mempertinggi daya serap belajar. Media visual yang digunakan berupa media gambar. Media gambar merupakan media visual yang praktis digunakan. Model discovery learning yang diterapkan dengan berbantuan media visual dapat memberikan peluang kepada siswa untuk berpatisipasi aktif dan siswa memperoleh pengalaman belajar yang lebih bermakna.

Penelitian ini juga didukung oleh penelitian lain yang relevan, yakni berdasarkan penelitian yang dilakukan oleh Putri (2019) dengan hasil penelitian menunjukkan bahwa hasil kompetensi pengetahuan IPA siswa yang mengikuti model pembelajaran discovery learning berbantuan lingkungan lebih tinggi daripada siswa yang tidak mengikuti model pembelajaran discovery learning berbantuan lingkungan di SD Negeri Gugus II Kuta Utara Tahun Pelajaran 2017/2018. Hal ini ditunjukkan dari hasil uji-t yang diperoleh yaitu thitung $(3,926)>t_{\text {tabel }}(1,998)$ yang menandakan terdapat perbedaan yang signifikan pada hasil kompetensi pengetahuan IPA siswa yang dibelajarkan dengan model pembelajaran discovery learning berbantuan lingkungan dengan siswa yang tidak dibelajarkan dengan model pembelajaran discovery learning berbantuan lingkungan pada siswa kelas kelas $\mathrm{V}$ SD Negeri Gugus II Kuta Utara Tahun Pelajaran 2017/2018. Persamaan penelitian tersebut dengan penelitian ini terletak pada model pembelajaran yang diterapkan. Sedangkan perbedaan penelitian tersebut dengan penelitian ini yaitu model pembelajaran yang diterapkan berbantuan lingkungan dan kompetensi pengetahuan IPA.

Penelitian yang dilakukan oleh Widiatmika (2017) dengan hasil penelitian menunjukkan bahwa hasil kompetensi pengetahuan IPS siswa yang mengikuti model pembelajaran discovery learning berbantuan media audio visual lebih tinggi daripada siswa yang tidak mengikuti model pembelajaran discovery learning berbantuan media audio 
visual di SD Gugus Letda Made Putra 2016/2017. Hal ini ditunjukkan dari hasil uji-t yang diperoleh yaitu $t_{\text {hitung }}(3,86)>t_{\text {tabel }}(2,000)$ yang menandakan terdapat perbedaan yang signifikan pada hasil kompetensi pengetahuan IPS siswa yang dibelajarkan dengan model pembelajaran discovery learning berbantuan media audio visual dengan siswa yang tidak dibelajarkan dengan model pembelajaran discovery learning berbantuan media audio visual pada siswa kelas IV SD Gugus Letda Made Putra 2016/2017. Persamaan penelitian tersebut dengan penelitian ini terletak pada model pembelajaran yang diterapkan. Sedangkan perbedaan penelitian tersebut dengan penelitian ini yaitu model pembelajaran yang diterapkan berbantuan media audio visual dan kompetensi pengetahuan IPS.

Penelitian yang dilakukan oleh Sudiarsini (2016) dengan hasil penelitian menunjukkan bahwa hasil belajar IPA siswa yang mengikuti model pembelajaran kooperatif STAD berbantuan media visual lebih tinggi daripada siswa yang tidak mengikuti model pembelajaran kooperatif STAD berbantuan media visual di SD Gugus IV Kecamatan Sawan Tahun Pelajaran 2015/2016 . Hal ini ditunjukkan dari hasil uji-t yang diperoleh yaitu $t_{\text {hitung }}(4,4)>t_{\text {tabel }}(2,101)$ yang menandakan terdapat perbedaan yang signifikan pada hasil belajar IPA siswa yang dibelajarkan dengan model pembelajaran kooperatif STAD berbantuan media visual dengan siswa yang tidak dibelajarkan dengan model pembelajaran kooperatif STAD berbantuan media visual pada siswa kelas kelas V SD Gugus IV Kecamatan Sawan Tahun Pelajaran 2015/2016. Persamaan penelitian tersebut dengan penelitian ini terletak pada media yang digunakan dan hasil belajar IPA. Sedangkan perbedaan penelitian tersebut dengan penelitian ini yaitu model pembelajaran yang diterapkan.

Penelitian yang dilakukan oleh Aptinata, (2017) dengan hasil penelitian menunjukkan bahwa hasil belajar IPS siswa yang mengikuti model pembelajaran discovery learning berbantuan LKS lebih tinggi daripada siswa yang tidak mengikuti model pembelajaran discovery learning berbantuan LKS di SD Gugus II Mengwi Tahun Pelajaran $2016 / 2017$. Hal ini ditunjukkan dari hasil uji-t yang diperoleh yaitu $t_{\text {hitung }}(5,983)>t_{\text {tabel }}$ $(2,000)$ yang menandakan terdapat perbedaan yang signifikan pada hasil belajar IPS siswa yang dibelajarkan dengan model pembelajaran discovery learning berbantuan LKS dengan siswa yang tidak dibelajarkan dengan model pembelajaran discovery learning berbantuan LKS pada siswa kelas V SD Gugus II Mengwi Tahun Pelajaran 2016/2017. Persamaan penelitian tersebut dengan penelitian ini terletak pada model pembelajaran yang diterapkan. Sedangkan perbedaan penelitian tersebut dengan penelitian ini yaitu model pembelajaran yang diterapkan berbantuan LKS dan hasil belajar IPS. Berdasarkan hasil penelitian relevan yang telah dipaparkan, dapat disimpulkan bahwa model discovery learning berbantuan media visual sangat berpengaruh terhadap hasil belajar siswa.

Penelitian yang dilakukan oleh Supradnyana (2016) dengan hasil penelitian menunjukkan bahwa hasil belajar IPA siswa yang mengikuti model pembelajaran discovery learning berbantuan audio visual lebih tinggi daripada siswa yang tidak mengikuti model pembelajaran discovery learning berbantuan audio visual di SD Gugus XV Kecamatan Buelelng Tahun Pelajaran 2015/2016. Hal ini ditunjukkan dari hasil uji-t yang diperoleh yaitu $t_{\text {hitung }}(3,299)>t_{\text {tabel }}(2,002)$ yang menandakan terdapat perbedaan yang signifikan pada hasil belajar IPA siswa yang dibelajarkan dengan model pembelajaran discovery learning berbantuan audio visual dengan siswa yang tidak dibelajarkan dengan model pembelajaran discovery learning berbantuan audio visual pada siswa kelas IV SD Gugus XV Kecamatan Buleleng Tahun Pelajaran 2015/2016. Persamaan penelitian tersebut dengan penelitian ini terletak pada model pembelajaran yang diterapkan dan hasil belajar IPA. Sedangkan perbedaan penelitian tersebut dengan penelitian ini yaitu model pembelajaran yang diterapkan berbantuan audio visual.

Penelitian yang dilakukan oleh Armini (2017) dengan hasil penelitian menunjukkan bahwa hasil belajar IPA siswa yang mengikuti model pembelajaran think talk write lebih tinggi daripada siswa yang tidak mengikuti model pembelajaran think talk write di SD Gugus II Kecamatan Buleleng Tahun Pelajaran 2016/2017. Hal ini ditunjukkan dari 
hasil uji-t yang diperoleh yaitu $t_{\text {hitung }}(6,59)>t_{\text {tabel }}(2,014)$ yang menandakan terdapat perbedaan yang signifikan pada hasil belajar IPA siswa yang dibelajarkan dengan model pembelajaran think talk write dengan siswa yang tidak dibelajarkan dengan model pembelajaran think talk write kelas IV semester II SD Gugus II Kecamatan Buleleng Tahun Pelajaran 2016/2017. Persamaan penelitian tersebut dengan penelitian ini terletak pada hasil belajar IPA. Sedangkan perbedaan penelitian tersebut dengan penelitian ini yaitu model pembelajaran yang diterapkan. Berdasarkan hasil penelitian relevan yang telah dipaparkan, dapat disimpulkan bahwa model discovery learning berbantuan media visual sangat berpengaruh terhadap hasil belajar siswa.

Berdasarkan uraian diatas, maka dilaksanakan penelitian yang berjudul Pengaruh Model Discovery Learning Berbantuan Media Visual Terhadap Hasil Belajar IPA Siswa Kelas IV di Gugus XIII Kecamatan Buleleng Tahun Pelajaran 2019/2020.

Tujuan yang ingin dicapai pada penelitian ini yaitu untuk mengetahui pengaruh yang signifikan model discovery learning berbantuan media visual terhadap hasil belajar IPA siswa kelas IV di Gugus XIII Kecamatan Buleleng Tahun Pelajaran 2019/2020.

\section{METODE PENELITIAN}

Penelitian ini menggunakan desain penelitian eksperimen semu. Rancangan penelitian yang digunakan yaitu desain non-equivalent post-test only control group design (Mahendra, 2017)

Populasi adalah keseluruhan objek dalam suatu penelitian. Pernyataan tersebut didukung oleh Sudjana (dalam Agung, 2014) yang menyatakan populasi ialah totalitas semua nilai yang mungkin, hasil menghitung maupun pengukuran, kuantitatif maupun kualitatif daripada karakteristik tertentu mengenai sekumpulan objek yang lengkap dan jelas. Populasi yang digunakan pada penelitian ini adalah seluruh siswa kelas IV di Gugus XIII Kecamatan Buleleng Tahun Pelajaran 2019/2020 yang berjumalah 179 orang. Untuk meyakinkan bahwa kelima kelas tersebut memiliki kemampuan yang setara, maka kelima kelas tersebut diuji kesetaraan kemampuannya dengan menggunakan uji ANAVA satu jalur. Berdasarkan hasil uji kesetaraan diperoleh harga $F_{\text {hitung }}=0,22$ dan harga $F_{\text {tabel }}=2,15$ pada taraf signifikan 5\% sehingga $\mathrm{H}_{0}$ diterima dan $\mathrm{H}_{1}$ ditolak. Hasil tersebut menunjukkan bahwa tidak terdapat perbedaan yang signifikan hasil belajar IPA siswa kelas IV di Gugus XIII Kecamatan Buleleng Tahun Pelajaran 2019/2020. Dengan demikian, hasil belajar IPA siswa kelas IV di Gugus XIII Kecamatan Buleleng Tahun Pelajaran 2019/2020 adalah setara.

Setelah melakukan uji kesetaraan akan dilanjutkan dengan penentuan sampel. Menurut Riduwan (2013) sampel adalah bagian dari populasi yang mempunyai ciri-ciri atau keadaan tertentu yang akan diteliti. Teknik pengambilan sampel pada penelitian ini adalah teknik random sampling yang digunakan adalah cluster random sampling. Seluruh kelas yang sudah diuji kesetaraanya diundi untuk menentukan kelompok eksperimen dan kelompok kontrol. Undian dilakukan dengan menulis semua kelas IV yang ada di Gugus XIII Kecamatan Buleleng Tahun Pelajaran 2019/2020 dalam kertas kecil yang kemudian digulung. Selanjutnya akan diambil dua gulungan kertas yang hasilnya gulungan kertas pertama yang diambil dari undian dijadikan kelompok eksperimen dan gulungan kertas kedua yang diambil dari undian dijadikan kelompok kontrol. Hasil undian menunjukkan kelas IVA dari SDN 1 Baktiseraga sebagai kelas eksperimen dan kelas IV dari SDN 2 Banjar Tegal sebagai kelas kontrol.

Dalam penelitian ini, metode yang digunakan untuk mengumpulkan data adalah metode tes. Tes merupakan suatu metode penelitian psikologis untuk memperoleh informasi tentang berbagai aspek dengan menggunakan pengukuran yang menghasilkan suatu deskripsi kuantitatif tentang aspek yang diteliti seperti yang dikemukakan oleh (Agung, 2016). Tes hasil belajar yang digunakan disesuaikan dengan jenjang kemampuan kognitif siswa, dalam penelitian ini kemampuan kognitif siswa yang diukur dari tingkat 
kognitif C3 sampai C5. Jenis tes yang digunakan berupa tes pilihan ganda. Setiap soal disertai dengan 4 alternatif jawaban yang bisa dipilih siswa yaitu (a, b, c, dan d). Setiap item soal diberikan skor (1) bila menjawab benar dan skor (0) apabila menjawab salah. Tes pilihan ganda yang diberikan berjumlah 25 butir soal dengan tingkat kongnitif C3 samapi C5. Selanjutnya dilakukan uji validitas oleh pakar yang membidangi IPA dan dilakukan tes uji coba. Sebanyak 25 butir soal tersebut diberikan kepada siswa kelas IV dengan tujuan validasi tes. Setelah itu dilakukan uji validitas isi, validitas butir tes, uji reliabilitas, uji tingkat kesukaran, dan uji daya beda. Hasil validasi tes sebanyak 20 butir diberikan kepada siswa kelas eksperimen dan kelas kontrol sebagai post-test. Teknik analisis data yang digunakan dalam penelitian ini yaitu menggunakan statistik deskriptif dan statistik inferensial. Statistik deskrptif berfungsi untuk mengelompokkan data, menyelesaikan, memaparkan, dan menyajikan hasil olahan data. Statistik deskriptif yang digunakan dalam penelitian ini adalah nilai rata-rata (mean) dan standar deviasi. Teknik yang digunakan untuk menganalisis data dan untuk menguji hipotesis penelitian adalah uji-t. Koyan (2012) menyatakan uji-t digunakan untuk menguji perbedaan nilai rata-rata hitung antara dua kelompok sampel berkorelasi dan sampel independen. Sebelum melakukan uji hipotesis, ada beberapa prasyarat yang harus terpenuhi yaitu data harus dalam keadaan berdistribusi normal dan varians homogen. Kedua prasyarat tersebut harus dibuktikan terlebih dahulu, maka untuk memenuhi hal tersebut dilakukan uji prasyarat analisis dengan melakukan uji normalitas sebaran data dan uji homogenitas.

\section{HASIL DAN PEMBAHASAN}

\section{HASIL}

Data penelitian ini adalah skor hasil belajar IPA kelompok siswa yang dibelajarkan menggunakan model discovery learning berbantuan media visual dan kelompok siswa yang dibelajarkan tidak menggunakan model discovery learning berbantuan visual. Rekapan deskripsi data hasil belajar IPA siswa dapat dilihat pada Tabel 2.

Tabel 2. Hasil Belajar IPA

\begin{tabular}{lcc}
\hline \multicolumn{1}{c}{ Statistik Deskriptif } & Kelompok Eksperimen & Kelompok Kontrol \\
\hline Mean & 15,07 & 12,46 \\
Standar Deviasi & 1,96 & 2,72 \\
Varians & 3,84 & 7,40 \\
Skor Tertinggi & 19 & 18 \\
Skor Terendah & 11 & 7 \\
\hline
\end{tabular}

Bersumber dari tabel 2 data hasil belajar IPA siswa yang dibelajarkan menggunakan model discovery learning berbantuan media visual sebagai kelompok eksperimen terhadap 28 siswa menunjukkan skor tertinggi adalah 19 dan skor terendah adalah 11. Berdsarakan hasil perhitungan diperoleh hasil mean $=15,07$, standar deviasi $=$ 1,96 dan varians $=3,84$. Selanjutnya data hasil belajar IPA dikonverensikan dengan mengikuti kategori skala lima menggunakan kriteria rata-rata ideal (Mi) dan standar deviasi ideal (SDi). Adapun hasil perhitungan konverensi data hasil belajar IPA kelompok eksperimen diketahui bahwa rata-rata hasil belajar IPA termasuk kategori sangat baik, yaitu 15,07 yang berada pada rentangan skor $15 \leq \mathrm{M}<20$. Sedangkan hasil belajar IPA siswa yang dibelajarakn tidak menggunakan model pembelajaran discovery learning sebagai kelompok kontrol terhadap 25 siswa menunjukkan skor tertinggi adalah 18 dan skor 
terendah adalah 7. Berdasarkan hasil perhitungan diperoleh hasil mean $=12,46$, standar deviasi $=2,72$ dan varians $=7,40$. Selanjutnya data hasil belajar IPA dikonverensikan dengan mengikuti kategori skala lima menggunakan kriteria rata-rata ideal (Mi) dan standar deviasi ideal (SDi). Adapun hasil perhitungan konverensi data hasil belajar IPA kelompok kontrol diketahui bahwa rata-rata hasil belajar IPA termasuk kategori baik, yaitu 12,46 yang berada pada rentanfan skor $11,67 \leq \mathrm{M}<15$.

Uji prasyarat analisis meliputi uji normalitas dan homogenitas terhadap data skor hasil belajar IPA melalui post-test. Uji normalitas dilakukan untuk menyajikan bahwa sampel benar-benar berasal dari populasi berdistribusi normal. Uji normalitas sebaran data dilakukan terhadap data hasil belajar IPA kelompok eksperimen dan kelompok kontrol. Berdasarkan analisis data yang telah dilakukan, dapat disajikan rekapitulasi hasil normalitas data hasil belajar IPA siswa kelompok eksperimen dan kelompok kontrol pada Tabel 3.

Tabel 3. Rekapitulasi Hasil Uji Normalitas Sebaran Data Hasil Belajar IPA

\begin{tabular}{llccc}
\hline No & $\begin{array}{c}\text { Kelompok Data Hasil } \\
\text { Belajar }\end{array}$ & $\chi_{\text {hitung }}^{2}$ & $\begin{array}{c}\chi_{\text {tabel }}^{2} \text { Taraf signifikan } \\
5 \%\end{array}$ & Status \\
& & & & \\
\hline 1 & Post-test Eksperimen & 2,69 & 11,07 & Normal \\
2 & Post-test Kontrol & 3,68 & 11,07 & Normal
\end{tabular}

Uji normalitas sebaran data dihitung dengan menggunakan rumus rumus chisquare. Hasil perhitungan dengan rumus chi-square, diperoleh hasil $\mathrm{X}^{2}$ hitung kelompok eksperimen adalah 2,69 dan hasil $\mathrm{X}^{2}$ hitung kelompok kontrol 3,68 lebih kecil dari $\mathrm{X}_{\text {tabel }}^{2}$ yaitu 11.07, sehingga dapat disimpulkan semua sebaran data hasil belajar IPA siswa berdistribusi normal.

Sedangkan uji homogenitas varians antar kelompok bertujuan untuk memeriksa kesamaan varians antar kelompok perlakuan. Dalam penelitian ini, uji homogenitas dilakukan terhadap varians pasangan antar kelompok eksperimen dan kelompok kontrol. Uji yang digunakan adalah Uji-F dengan kriteria data homogen $\mathrm{F}_{\text {hitung }} \leq \mathrm{F}_{\text {tabel }}$. Hasil perhitungan diperoleh nilai $\mathrm{F}_{\text {hitung }}$ pada kelompok eksperimen dan kelompok kontrol adalah 1,93 dan $F_{\text {tabel }}=4,03$. Hal ini berarti $F_{\text {hitung }} \leq F_{\text {tabel }}$, sehingga varians data hasil belajar IPA kelompok eksperimen dan kelompok kontrol adalah homogen.

Mengacu pada uji prasyarat setelah data hasil belajar IPA sudah normalitas dan homogen, maka dilanjutkan pada uji hipotesis. Pengujian hipotesis tersebut dilakukan menggunakan uji-t sampel independent (tidak berkorelasi) dengan rumus polled varians dengan kriteria pengujian $\mathrm{H}_{0}$ ditolak jika $\mathrm{t}_{\text {hitung }}>\mathrm{t}_{\text {tabel }}$ dan $\mathrm{H}_{0}$ diterima jika $\mathrm{t}_{\text {hitung }}<\mathrm{t}_{\text {tabel. }}$. Hasil uji hipotesis disajikan pada Tabel 4.

Tabel 4. Rekapitulasi Hasil Perhitungan Uji-t

\begin{tabular}{lcccccc}
\hline \multicolumn{1}{c}{ Kelompok } & $\mathrm{N}$ & $\bar{X}$ & $\mathrm{~s}^{2}$ & $\mathrm{Db}$ & $\mathrm{t}_{\text {hitung }}$ & $\begin{array}{c}\mathrm{T}_{\text {tabel }} \text { dengan taraf } \\
\text { signifikansi 5\% }\end{array}$ \\
\hline Eksperimen & 28 & 15,07 & 3,84 & 51 & 3,95 & 2,000 \\
Kontrol & 25 & 12,46 & 7,40 & & & \\
\hline
\end{tabular}

Bersumber dari Tabel 4 hasil perhitungan uji-t, diperoleh $t_{\text {hitung }}=3,95$ dan $t_{\text {tabel }}=$ 2,000 pada taraf signifikansi $5 \%$. Dengan demikian, nilai $t_{\text {hitung }}(3,95)>t_{\text {tabel }}(2,000)$ 
sehingga $\mathrm{H}_{0}$ ditolak dan $\mathrm{H}_{1}$ diterima. Hal ini menunjukkan bahwa terdapat pengaruh yang signifikan model pembelajaran discovery learning berbantuan media visual terhadap hasil belajar IPA siswa kelas IV Gugus XIII Kecamatan Buleleng Tahun Pelajaran 2019/2020.

Berdasarkan deskripsi data hasil penelitian yang telah dilakukan, diketahui bahwa terdapat pengaruh yang signifikan model discovery learning berbantuan media visual terhadap hasil belajar IPA siswa kelas IV Gugus XIII Kecamatan Buleleng Tahun Pelajaran 2019/2020. Siswa yang mengikuti pembelajaran dengan menggunakan model discoveri learning menunjukkan hasil belajar IPA meningkat. Hal ini dilihat dari hasil uji-t yang diperoleh yaitu $t_{\text {hitung }}(3,95)>t_{\text {tabel }}(2,000)$ pada taraf signifikansi $5 \%$.

\section{PEMBAHASAN}

Dengan adanya pengaruh yang signifikan model discovery learning berbantuan media visual terhadap hasil belajar IPA siswa kelas IV Gugus XIII Kecamatan Buleleng Tahun Pelajaran 2019/2020. Hal ini disebabkan oleh langkah-langkah dari model discovery learning berbantuan media visual yang mampu melibatkan siswa secara langsung dalam mencari dan menemukan sendiri konsep atau prinsip melalui percobaan sederhana yang dilakukan. Dalam aktivitas pembelajaran, aktivitas belajar siswa lebih banyak dibandingkan dengan aktivitas guru. Hal ini terjadi karena siswa diberikan kesempatan untuk menggali pengetahuan yang dimiliki melalui percobaan sederhana serta bekerjasama dalam kelompok guna menyelesaikan suatu masalah.

Tahap pertama model discovery learning berbantuan media visual adalah stimulation. Stimulation berarti memulai kegiatan pembelajaran dengan mengajukan pertanyaan, anjuran membaca buku, dan aktivitas lainnya yang mengarah pada persiapan (Supradnyana, dkk., 2016). Pada tahap ini, siswa mengamati gambar yang ditayangkan oleh guru sesuai dengan materi yang dibelajarkan. Dalam hal ini siswa yang tadinya mengantuk menjadi lebih memperhatikan dan menyimak penjelasan guru serta antusias siswa pada media yang digunakan oleh guru. Melalui penayangan gambar, siswa terlibat secara langsung dengan materi yang dipelajari. Hal tersebut sesuai dengan pendapat Sudiarsini (2016) yang menyatakan bahwa penggunaan media visual dapat meningkatkan pemahaman secara langsung antara siswa dengan materi yang dipelajari. Sifatnya yang konkret, membuat media visual lebih realistis untuk menunjukkan materi pokok sehingga kondisi ini dapat mengembangkan dan membantu siswa untuk melakukan eksplorasi.

Tahap kedua yaitu problem statement, pada tahap ini siswa diberikan kesempatan untuk mengidentifikasi sebanyak mungkin masalah yang relevan dari gambar yang telah ditayangkan. Kemudian siswa memilih salah satu masalah dan dirumuskan dalam bentuk hipotesis. Permasalahan yang dipilih itu selanjutnya dirumuskan dalam bentuk hipotesis yakni berupa statement sebagai jawaban sementara atas pertanyaan yang diajukan. Dalam hal ini siswa mengerjakan LKPD secara berkelompok. Dengan melakukan identifikasi suatu masalah siswa menjadi mencari dan dapat memilih masalah yang ada. Mengacu dalam kegiatan ini memberikan kesempatan siswa untuk mengidentifikasi dan menganalisis masalah yang dihadapi, maka secara tidak langsung siswa sudah mengembangkan ranah kognitif $\mathrm{C} 4$ yaitu menganalisis.

Tahap ketiga adalah data collection, siswa membuktikan benar atau tidaknya hipotesis. Siswa diberi kesempatan untuk mengumpulkan informasi yang relevan. Dalam hal ini siswa melakukan percobaan sederhana untuk membuktikan benar atau tidaknya hipotesis yang dibuat. Kegiatan ini melatih siswa berpikir ilmiah dan belajar secara aktif untuk menemukan sesuatu yang berhubungan dengan permasalahan yang dihadapi sehingga secara tidak sengaja siswa menghubungkan masalah dengan pengetahuan yang telah dimiliki. Hal ini sejalan dengan kelebihan model discovery learning yaitu memberikan kesempatan siswa untuk melatih berpikir ilmiah dan belajar secara aktif (Kurniasih \& Sani, 2014). Dengan demikian secara tidak langsung siswa sudah mengembangkan ranah kognitif C3 pada kegiatan menggunakan prosedur percobaan. 
Tahap keempat adalah data processing, tahap ini berarti kegiatan mengolah data dan informasi yang telah diperoleh para siswa baik melalui wawancara, observasi dan lain sebagainya. Siswa memperoleh informasi dari hasil percobaan sederhana yang telah dilakukan. Kemudian informasi tersebut diolah melalui diskusi dan saling bertutukar pikiran antar anggota kelompok. Dengan berdiskusi siswa dapat mengembangkan daya berpikir dan saling bertukar pikaran antar anggota kelompok. Dalam kegiatan ini siswa mengalami keseruan, kebersamaan dengan kelompok dan dapat mengeluarkan pendapatnya.

Tahap kelima adalah verification, siswa memeriksa secara cermat untuk membuktikan benar atau tidaknya hipotesis yang ditetapkan kemudian dihubungkan dengan data processing (Candra, dkk., 2017). Setelah siswa mendapatkan hasil pengolahan data dan informasi, selanjutnya hipotesis yang telah dirumuskan terdahulu kemudian dicek, apakah terbukti atau tidak. Dalam kegiatan ini, siswa mengecek kembali dari hasil diskusi yang diperoleh melalui percobaan yang telah dilakukan. Dalam hal ini memberikan kesempatan siswa untuk menemukan konsep, teori, atau pemahaman melalui contohcontoh yang siswa jumpai dalam kehidupannya. Mengacu pada hal tersebut siswa dapat mengembangkan ranah kognitif C5 yaitu membuktikan.

Tahap keenam adalah generalization, pada tahap ini proses menarik kesimpulan. Siswa menarik kesimpulan dari permasalahan yang ditemui dengan memperhatikan hasil verification. Pada tahap generalizition, guru membuka kesempatan kepada kelompokkelompok kecil untuk mempersentasikan hasil diskusi. Terkait hal ini ditunjuk salah satu siswa untuk mempersentasikan hasil diskusi di depan sehingga kelompok yang lain bisa menambahkan atau menyanggah dari jawaban yang disampaikan. Selain itu, guru bisa memberikan penguatan dari hasil diskusi yang disampaikan. Dengan adanya hal tersebut, mendorong siswa untuk termotivasi ke depan untuk menyampaikan hasil diskusi.

Hasil penelitian ini didukung beberapa penelitian yang terkait dengan penggunaan model discovery learning. Riantari (2017), melakukan penelitian tentang Pengaruh Model Pembelajaran Discovery Learning Berbantuan Media Lingkungan Terhadap Kompetensi Pengetahuan IPA, dilihat dari hasi penelitian kegiatan pembelajaran tersebut dapat menciptakan situasi yang dapat membuat siswa belajar secara aktif untuk membangun konsep dan prinsip - prinsip IPA. Hal ini terjadi proses pembelajaran dilaksanakan pada alam nyata, dapat menambah pengetahuan siswa dan pembelajaran tidak membosankan.

Baroroh (2019) melakukan penelitian tentang Pengaruh Model Discovery Learning Berbantuan Anyaman Terhadap Kemampuan Pemahaman Konsep Matematika Siswa, dilihat dari hasil penelitian kegiatan pembelajaran tersebut mampu mencapai ketuntasan belajar siswa saat diberikan perlakuan dengan model discovery learning. Hal ini dikarenakan langkah-langkah model discovery learning diarahkan untuk menemukan sendiri konsepnya. Selain itu, situasi pembelajaran yang aktif dan tidak membosankan.

Aptinata, (2017) melakukan penelitian tentang Pengaruh Model Discovery Learning Berbantuan LKS Terhadap Hasil Belajar IPS, dilihat dari hasil penelitian kegiatan pembelajaran tersebut mampu mencapai ketuntasan belajar siswa saat diberikan perlakuan dengan model discovery learning. Hal ini dikarenakan model discovery mampu membuat siswa lebih aktif, terlihat dalam pemecahan masalah, serta siswa terbiasa untuk mengungkapkan pendapat yang dimiliki sehingga dapat meningkatkan hasil belajar siswa.

Agustin, (2019) melakukan penelitian tentang Pengaruh Model Pembelajaran TPS Berbantuan Media Visual Terhadap Hasil Belajar IPA. dengan adanya media visual siswa lebih bersemangat mengikuti pembelajaran dan meningkatnya hasil belajar yang pada akhirnya berdampak pada hasil pembelajaran. Untuk itu, penggunaan model discovery learning berbantuan media visual perlu ditingkatkan dan disosialisasikan pada setiang sub pokok bahasan pembelajaran IPA. Model Discovery Leraning Berbantuan Media Visual dapat dijadikan salah satu alternative solusi dalam meningkatkan hasil belajar IPA.

Dengan demikian dapat dinyatakan bahwa model discovery learning berbantuan media visual berpengaruh positif terhadap hasil belajar IPA siswa kelas IV di Gugus XIII 
Kecamatan Buleleng Tahun Pelajaran 2019/2020. Pemberian perlakuan model discovery learning dalam proses pembelajaran mendorong siswa untuk berpikir sendiri, belajar sendiri, tanpa harus tergantung penuh kepada guru. Siswa terlibat langsung dalam mencari dan menemukan sendiri konsep atau prinsip melalui percobaan sederhana yang dilakukan untuk menyelesaikan masalah yang ditemui. Model discovery learning semakin menarik dan dapat meningkatkan hasil belajar dengan adanya bantuan media visual. Dengan media visual siswa akan lebih mudah memahami suatu materi apabila dibantu dengan media. Penggunaan media visual dapat meningkatkan pemahaman secara langsung antara siswa dengan materi yang dipelajari. Sifatnya yang konkret, membuat media visual lebih realistis untuk menunjukkan materi pokok. Selain itu, pemanfaatan media visual dapat meningkatkan rasa ingin tahu siswa, memotivasi siswa untuk belajar dan meningkatkan keaktifan siswa selama mengikuti proses pembelajaran. Jadi, model discovery learning berbantuan media visual sangat baik diterapkan untuk meningkatkan hasil belajar IPA siswa.

\section{SIMPULAN DAN SARAN}

Berdasarkan hasil penelitian dan pembahasan diatas, dapat disimpulkan bahwa terdapat pengaruh yang signifikan model discovery learning berbantuan media visual terhadap hasil belajar IPA siswa kelas IV di Gugus XIII Kecamatan Buleleng Tahun Pelajaran 2019/2020. Hal ini dapat dilihat dari uji-t yang diperoleh hasil signifikan sebesar $\mathrm{t}_{\text {hitung }}(3,95)>\mathrm{t}_{\text {tabel }}(2,000)$. Berdasarkan kriteria pengujian, $\mathrm{H}_{0}$ ditolak dan $\mathrm{H}_{1}$ diterima yang menunjukkan terdapat pengaruh yang signifikan model discovery learning berbantuan media visual terhadap hasil belajar IPA siswa kelas IV di Gugus XIII Kecamatan Buleleng Tahun Pelajaran 2019/2020. Dengan adanya pengaruh yang signifikan ini membuktikan bahwa terdapat pengaruh positif model discovery learning berbantuan media visual terhadap hasil belajar IPA siswa kelas IV di Gugus XIII Kecamatan Buleleng Tahun Pelajaran 2019/2020.

\section{DAFTAR PUSTAKA}

Agung, A. A. (2014). Metodologi Penelitian Pendidikan. Malang: Aditya Media Pubblish.

Agung, A. A. G. (2016). Statistik Dasar untuk Pendidikan. Yogyakarta: Deepublish.

Agustin, N. K. T. J., Margunayasa, I. G., \& Kusmariyatni, N. N. (2019). Pengaruh Model Pembelajaran TPS Berbantuan Media Visual Terhadap Hasil Belajar IPA. Journal for Lesson and Learning Studies, 2(2), 239-249.

Aptinata, I. M. R. W., Putra, D. K. N. S., \& Sujana, I. W. (2017). Pengaruh Model Discovery Learning Berbantuan LKS Terhadap Hasil Belajar IPS Siswa Kelas V. EJournal Edutech Universitas Pendidikan Ganesha, 5(2), 1-9.

Armini, N. P. S., Wibawa, I. M. C., \& Murda, I. N. (2017). Pengaruh Model Pembelajaran Think Talk Write Terhadap Hasil Belajar IPA pada Siswa Kelas IV SD. E-Journal PGSD Universitas Pendidikan Ganesha, 5(2).

Astuti, Y. W., Mustadi, A., \& Yogyakarta, U. N. (2015). Effects of the use of animation film media on the narrative text writing skill of grade V students of ESs. Jurnal Prima Edukasia, 2(2), 250-262.

Baroroh, N., Ulya, H., \& Rahayu, R. (2019). Pengaruh Model Discovery Learning Berbantuan Media Anyaman Terhadap Kemampuan Pemahaman Konsep Matematis Siswa. Jurnal Prakarsa Paedagogia, 2(1).

Candra, A. A. B. T. A., Sujana, I. W., \& Ardana, I. K. (2017). Pengaruh Model Discovery 
Learning Terhadap Kompetensi Pengetahuan IPA Siswa Kelas VI SD Gugus Yos Sudarso Kecamatan Denpasar Selatan Tahun Pelajaran 2016/2017. E-Journal PGSD Universitas Pendidikan Ganesha, 5(2).

Dewi, N. N. R., Suara, I. M., \& Wiarta, I. W. (2016). Penerapan Model Discovery Learning Berbantuan Media Konkret Dapat Meningkatkan Penguasaan Kompetensi Pengetahuan IPA Kelas VB. E-Journal PGSD Universitas Pendidikan Ganesha, 4(1).

Indriani. (2019). Hasil PISA Tunjukkan Perspektif Pendidikan Indonesia Tersediahttps://www.antaranews.com/berita/1191792/mendikbud-hasil-pisatunjukkan-perspektif-pendidikan-indonesia. Diakses pada 15 Mei 2020.

Koyan, I. W. (2012). Statistik Pendidikan Teknik Data Kuantitatif. Singaraja: Undiksha Press.

Kurniasih, I, \& Sani, B. (2014). Suses Mengimplementasikan Kurikulum 2013. Yogyakarta: Kata Pena.

Kurniasih, Imas, \& Sani, B. (2014). Sukses Mengimplementasikan Kurikulum 2013. Yogyakarta: Kata Pena.

Mahendra, I. W. E. (2017). Project Based Learning Bermuatan Etnomatematika dalam Pembelajaran Matematika. Jurnal Pendidikan Indonesia, 6(1), 106-114.

Mahendra, I. W. E., Parmithi, N. N., Suana, I. W., \& Sumandya, I. W. (2019). Developing Hots Through Performance Assessment. International Journal of Scientific \& Technology Reseacrh, 8(12), 3004-3007.

Noviyanti, N. L. D., Lestari, L. P. S., \& Ganesha, U. P. (2017). Pengaruh Model Pembelajaran Kooperatif Tipe Snowball Throwing Terhadap Hasil Belajar IPA Siswa Kelas IV. E-Journal PGSD Mimbar PGSD, 5(2).

Purwanti, K. Y., Suryani, E., \& Waluyo, U. N. (2018). Pengaruh Discovery Learning dengan Pendekatan Scientific Berbantuan Powtoon Terhadap Motivasi dan Kemampuan Berpikir Kritis. Janacitta, 1(01).

Putrayasa, I. M., Syahruddin, H., \& Margunayasa, I. G. (2014). Pengaruh Model Pembelajaran Discovery Learning dan Minat Belajar Terhadap Hasil Belajar IPA Siswa. Jurnal Mimbar PGSD Universitas Pendidikan Ganesha, 2(1).

Putri, N. M. C. D., Ardana, I. K., \& Agustika, G. N. S. (2019). Pengaruh Model Discovery Learning Berbantuan Lingkungan Terhadap Kompetensi Pengetahuan IPA Siswa Kelas V. Mimbar PGSD Undiksha, 7(2), 57-64.

Rediarta, I. W. (2014). Pengaruh Model Kooperatif Two Stay Two Stray Terhadap Hasil Belajar IPA. Mimbar PGSD Universitas Pendidikan Ganesha, 2(1).

Riantari, I. A. P. C., Asri, I. G. A. A. S., \& Ganing, N. N. (2017). Pengaruh Model Discovery Learning Berbantuan Media Lingkungan Terhadap Kopetensi Pengetahuan IPA Kelas V SD. E-Journal PGSD Universitas Pendidikan Ganesha, $5(2)$.

Riastini, P. N. (2016). Pembelajaran IPA SD. Singaraja: Undiksha Press.

Riduwan. (2013). Dasar-dasar Statistika. Bandung: Alfabeta.

Sudiarsini, M., Agung, A. A. G., \& Parmiti, D. P. (2016). Pengaruh Model Pembelajaran Kooperatif STAD Berbantuan Media Visual Terhadap Hasil Belajar IPA Kelas V SD. 


\section{E-Journal PGSD Universitas Pendidikan Ganesha, 4(1).}

Supradnyana, K. W. (2016). Pengaruh Model Pembelajaran Discovery Learning Berbantuan Media Audio Visual Terhadap Hasil Belajar IPA Kelas IV. E-Journal PGSD Universitas Pendidikan Ganesha, 4(1).

Supradnyana, K. W., Garminah, N. N., \& Rati, N. W. (2016). Pengaruh Model Pembelajaran Discovery Learning Berbantuan Audio Visual Terhadap Hasil Belajar IPA Kelas IV. E-Journal Edutech Universitas Pendidikan Ganesha, 4(1).

Susilana, R., \& Riyana, C. (2016). Media Pembelajaran. Bandung: Wacana Prima.

Utami, I. A. P. T., Wibawa, I. M. C., \& Rati, N. W. (2018). Pengaruh Model Pembelajaran Kooperatif Tipe Talking Stick Berbantuan Teka-Teki Silang Terhadap Hasil Belajar IPA. Mimbar PGSD Undiksha, 6(3), 185-193.

Widiatmika, D. G., Sujana, I. W., \& Ganing, N. N. (2017). Pengaruh Model Discovery Learning Berbantuan Media Audio Visual Terhadap Kompetensi Pengetahuan IPS Siswa Kelas IV. E-Journal PGSD Universitas Pendidikan Ganesha, 5(2), 1-8. 